NBER WORKING PAPER SERIES

\author{
DEMOGRAPHIC STRUCTURE AND \\ THE POLITICAL ECONOMY OF PUBLIC \\ EDUCATION
}

James M. Poterba

NBER Working Paper 5677

\author{
NATIONAL BUREAU OF ECONOMIC RESEARCH \\ 1050 Massachusetts Avenue \\ Cambridge, MA 02138 \\ July 1996
}

I am grateful to Marianne Bitler and Marci Smith for outstanding research assistance, to David Cutler, Angus Deaton, Victor Fuchs, Jonathan Gruber, Robert Inman, Lawrence Katz, Sam Preston, Kim Rueben, Richard Zeckhauser, and an anonymous referee for helpful comments, and to the Institute for Policy Reform, the Center for Advanced Study in Behavioral Sciences, and the National Science Foundation for research support. A data appendix for this project has been archived at the ICPSR in Ann Arbor, MI. This paper is part of NBER's research programs in Aging and Public Economics. Any opinions expressed are those of the author and not those of the National Bureau of Economic Research.

(C) 1996 by James M. Poterba. All rights reserved. Short sections of text, not to exceed two paragraphs, may be quoted without explicit permission provided that full credit, including $(\odot)$ notice, is given to the source. 


\title{
DEMOGRAPHIC STRUCTURE AND \\ THE POLITICAL ECONOMY OF PUBLIC \\ EDUCATION
}

\begin{abstract}
This paper examines the relationship between demographic structure and the level of government spending on K-12 education. Panel data for the U.S. states over the 1960-1990 period suggests that an increase in the fraction of elderly residents in a jurisdiction is associated with a significant reduction in per child educational spending. This reduction is particularly large when the elderly residents and the school-age population are from different racial groups. Variation in the size of the school-age population does not result in proportionate changes in education spending, so students in states with larger school-age populations receive lower per-student spending than those in states with smaller numbers of potential students. These results provide support for models of generational competition in the allocation of public sector resources. They also suggest that the effect of cohort size on government-mediated transfers must be considered in analyzing how cohort size affects economic well-being.
\end{abstract}

James M. Poterba

Department of Economics, E52-350

Massachusetts Institute of Technology

50 Memorial Drive

Cambridge, MA 02139-4307

and NBER 
Spending on primary and secondary education is the largest expenditure item it state and local government budgets. While tax-financed public education may provide some benefits to society and the local community at large, most of the return to such spending accrues to families with children. The costs of public education nevertheless fall on households with and without school-age children. In particular, older households with owner-occupied homes pay local property taxes as well as state sales and income taxes that ultimately finance K-12 education. These generational differences in the net benefits from publicly-provided education can lead to tensions in the political process in which education budgets are set. This paper explores the empirical significance of these generational tensions, and presents evidence suggesting that during the postwar period, a state's demographic composition has affected the level of per-child education spending.

Questions of intergenerational burden-sharing and equity in school finance have received less attention to date than intra-generational issues such as inequality in school district spending levels. The prospective aging of the United States' population, indicated by the projected growth of the population share aged age $65+$ from $12.5 \%$ in 1990 to $18.7 \%$ in 2030 , may however lead to heightened generational tensions and interest in these issues. These issues have already become salient in debates over Social Security, where younger workers are taxed to finance benefits for older retirees. The transfers in the public education system flow in the opposite direction.

The analysis presented below relates more generally to the analysis of how cohort size affects the well-being of cohort members. Traditional analyses of this 
issue in economic demography focus on the supply and demand for workers, and on the induced rates of return on various assets. Those in a large cohort must supply their labor when aggregate labor supply is high, so they are predicted to earn lower real wages than those in relatively smaller birth cohorts. Similarly, when those in large cohorts decide to save for retirement, they must compete with many other savers in buying assets, thereby bidding up prices and driving down returns. These two effects combine to reduce the lifetime utility of those in large birth cohorts relative to those in smaller cohorts.

This traditional analysis neglects the potentially important role of government transfers in altering the inter-cohort distribution of resources. Because the level and direction of government-mediated transfers reflect in part the relative political powers of different cohorts, those in small cohorts may receive smaller net transfers than those in larger cohorts. Preston [1984] suggests that such generational competition is part of the explanation for the relative improvement in the economic status of elderly households in the U.S., and the decline in the well-being of children, during the 1960-1980 period. This hypothesis is confirmed by at least anecdotal evidence on public support for various government programs. Recent survey results suggest that support for increased federal funding of public schools declines from 77 percent if the respondent is under 30 , to 47 percent for those over age 70 [Business Week, 3 April 1995, p. 42].

The theoretical relationship between demographic structure and the age-specific pattern of government spending is complex, in part because the age-specific benefits 
of various government programs may be difficult to assess. Richman and Stagner [1986], for example, develop an alternative to Preston's [1984] hypothesis that a rising number of elderly households will lead to greater government transfer flows toward this group. They suggest that rising numbers of dependent elderly may seek to raise the training of younger workers, both to raise the pool of resources from which transfers can be funded and to raise the quality of services they receive. Such alternative hypotheses make the relationship between the age structure of the population, and the level of age-specific transfers, an issue for empirical research.

The present paper explores the link between cohort size and spending patterns by focusing on the relationship between state and local education spending per child and three demographic variables: the share of the population over age 65, the share of the population of school age (5 through 17), and the difference in the racial composition of the elderly and school-age populations. The paper is divided into four sections. The first summarizes previous work on demographic structure and public spending determination, with particular attention to studies of public education. Section two presents the econometric specification that provides the basis for this study, and summarizes the demographic variation across the U.S. states. The third section presents regression evidence on the association between demographic structure and education spending, along with "control equations" that relate state and local spending for activities other than K-12 education to the same set of demographic variables. A brief conclusion suggests several limitations of the current analysis, as well as directions for future work. 


\section{Government-Mediated Redistribution Across Generations}

Government-provided retirement pensions, tax-financed national health care systems that transfer resources from those in the labor force to older individuals, and publicly provided education are the most prominent examples of government's substantial role in intergenerational redistribution. The relative levels of these various transfers differ substantially across countries. Table 1 presents a cross-national comparison of per capita social spending on children, middle-aged individuals, and the elderly in several large OECD nations. Per-child spending has been normalized to 100 for each nation. The table shows that spending on the elderly exceeds that on children in all of the countries, but that the ratio of spending per elderly individual to spending per child varies from 2.3 in Japan and Sweden to 3.8 in Italy and the United States.

The cross-national data do not suggest an obvious relationship between the share of the elderly in the population and the share of government spending devoted to the elderly or to children. Simple statistics such as those in Table 1 are virtually impossible to interpret, however, in the absence of other information on the relative incomes of different cohorts, the costs of providing services in different countries, and the nature of transfers that are not mediated by the government. ${ }^{1}$ Nevertheless the data suggest substantial differences across nations in the government transfer

'Further discussion of international comparisons may be found in O'Higgins [1988] and Smeeding, Torrey, and Rein [1988]. For a historical perspective on the growth of social spending in several OECD nations, with attention to demographic factors, see Lindert [1996]. 
component of the bargain that is struck between generations.

Searching for a link between demographic variables and spending outcomes raises an obvious question: how should potential demographic effects be modelled? Because there is no universally-accepted model of political equilibrium, it is difficult to invoke a maintained model of generational bargaining as a basis for developing econometric specifications for public spending on education or other directed expenditure programs that accrue to particular age groups. ${ }^{2}$ Different models can yield different answers to questions of the form "How will government spending on children change if the share of older individuals in the population increases?" In a median-voter framework, the answer to this question depends on whether the demographic shift changes the identity of the median voter. It is possible to shift the population age structure without changing the identity of the median voter, and therefore without affecting the political equilibrium or the age-specific structure of government transfer payments. In other models of political equilibrium, the relative size of different voting groups may affect spending outcomes. In this setting, a natural role for empirical work is to search for robust relationships between various demographic variables and the level of education spending.

\footnotetext{
${ }^{2}$ The notion that different groups within society compete for resources is the centerpiece of many models of distributive politics, such as that developed by Weingast, Shepsle, and Johnsen [1981]. Inman [1987] summarizes the many possible models that can be considered in analyzing the political process that determines policy outcomes. The special case of inter-generational bargaining involves particularly pronounced differences in the objectives of different participants in the political process, with age the primary determinant of interest group affiliation. Inman [1978] explicitly models demographic variables as shifting the median position and hence the behavior of the public sector.
} 
The political dynamic between different generations reduces to a simple transfer game when there are no cross-generational effects of directed spending. Whether a larger generation will succeed in transferring resources from smaller generations to itself depends, in this case, on the structure of the political process, and the degree to which protection against such transfers has been afforded to minority groups. This simple framework ignores cross-generational effects, however, which may be significant and which can make clear predictions very difficult. If individuals are altruistically linked to their parents and their children, then spending that raises the utility of the old will also raise the utility of the young, and vice versa. ${ }^{3}$ Even without such altruistic links, there may be cross-cohort direct utility effects associated with government spending. Spending on public education, for example, may reduce the incidence of crime and thereby raise utility of the old, while also raising the utility of the school-age children who receive this education, as well as their parents who are not required to arrange for private education. ${ }^{4}$ Such cross-effects make it difficult to build a satisfactory model of the political process that determines school spending.

In addition to generational affiliation, many other individual characteristics that may also determine the value of goods that benefit particular population sub-groups. Cutler, Elmendorf, and Zeckhauser (1993), who label such goods "directed goods," posit that ethnic group affiliation is one such characteristic. They argue that an

\footnotetext{
${ }^{3}$ Logan and Spitze [1995] present evidence of substantial intergenerational altruism with respect to public programs.

4Poterba [1995a] and Lott [1987] provide more detailed discussion of the externalities associated with public education.
} 
individual's support for a particular spending program depends on both age and ethnic proximity to the beneficiaries. This view is supported by anecdotal evidence. In Holyoke, Massachusetts, the Wall Street Journal [25 November 1991] reports, elderly white voters support programs that benefit young whites but not programs that benefit young non-whites, and this has resulted in sharply declining school outlays.

There are many ways to test for links between population age, ethnic composition and the level and mix of public spending. The cross-national evidence discussed above is one possibility, with the attraction that demographic composition differs substantially across nations. A crucial drawback, however, is that there are differences in the bundles of public goods provided in different nations, as well as differences in the non-government transfers across generations. Thus it is difficult to evaluate the cross-national data on government spending.

Studying differences in spending outcomes and demographic structure across U.S. states, or local jurisdictions such as school districts or counties, represents an alternative strategy for investigating how demographics affect the composition of public spending. The U.S. states represent a comparable set of jurisdictions with widely-available data on public spending, demographic characteristics, and numerous other variables that might impinge on spending choices. They also operate under broadly similar political institutions. One drawback of analyzing state-level data on spending and demographics is that many of the critical decisions on spending levels are made by voters in local jurisdictions. State average spending levels therefore conceal substantial heterogeneity within states. Studying local jurisdictions brings a 
different set of empirical problems, since the demographic composition of a small community cannot be viewed as exogenous, but rather depends on the structure of local public spending. This can make it impossible to generalize from the local-level relationship between demographic structure and spending patterns to broader-based changes.

There have been many previous empirical studies of the determinants of state spending, and a substantial fraction of these consider education spending in particular. Cutler, Elmendorf, and Zeckhauser [1993] survey much of this work, and present new empirical evidence relating state- and county-level per capita spending to the fraction of the population above age 65 , below age 18 , and the fraction of the county that is nonwhite. Their analysis combines all types of state and local government spending, including outlays on public hospitals, nursing homes, and on primary and secondary education. Separating these spending categories and focusing on particular types of spending, such as K-12 education spending, offers a more powerful method for testing hypotheses about demographic mix and spending levels, and motivates the analysis below.

Rubinfeld and Shapiro [1989] survey the substantial related literature on the demand for state and local spending on elementary education. The particular issue of interest in the current context is how demographic factors affect the demand for school spending, and this question has been considered in several previous studies. Rubinfeld [1977] analyzes data from a household survey and finds that age of household head does not have substantial explanatory power for school spending 
preferences, while an indicator variable for whether the household has children in the local public school system does have a substantial and positive effect on local public school support. ${ }^{5}$ Button [1992] finds that elderly Florida residents tend to vote against school bond issues, although they are not fiscally conservative in general. Downes [1996], however, finds a statistically insignificant relationship between the fraction of voters with school-aged children and the level of school spending in his analysis of post-Proposition 13 data on California.

Most of the previous work on the demand for education spending has concentrated on community-level variables and their impact on local spending, even though the growing role for state finance in K-12 education suggests that state-wide demographic patterns may also be of substantial consequence. State-wide referenda on property tax limits, for example, can have important effects on the level of education spending in each district, and provide an example of how state voter interests may affect the opportunity set of a local community. This is one attraction of using total state and local education spending within a state, as in the analysis presented below.

\section{Empirical Specification and Data Description}

The present project focuses on the relationship between state demographic

\footnotetext{
${ }^{5}$ Chomitz (1985) suggests that the relationship between having children in the schools, and supporting higher spending, is a robust finding that also appears in other studies. Both this study and Rubinfeld [1977] are concerned with whether an individual says he or she supports higher school spending, rather than with actual school spending outcomes.
} 
composition and the level of per-child education spending in the state. The empirical specification draws heavily on previous studies of state spending, including early work by Bergstrom and Goodman [1973] and Borcherding and Deacon [1973] and more recent studies by Case, Hines, and Rosen [1993] and Poterba [1995b]. Although studies of state-level spending are often motivated with a variant of the median voter model, in which demographic variables should not affect spending outcomes unless they affect the median voter's preferences, many "spending demand" studies justify including variables on demographic structure by arguing that they shift the local service production function, i.e. the level of spending that is needed to achieve a given level of output, rather than the political support for spending. ${ }^{6}$

The reduced form equation that is estimated below relates the logarithm of per child government spending on K-12 education? (ED/CHILD) to the logarithm of state real per capita personal income in the state (Y), the logarithm of real federal aid to K12 education (FEDAID), the logarithms of the population shares aged 5-17 (KID) and $65+$ (OLD), and the logarithms of the population shares that own homes (OWNERS), are nonwhite (NONWHITE), live in urban areas (URBAN), and live below the poverty

\footnotetext{
${ }^{8} \mathrm{Gross}$ [1995] presents in ingenious analysis of the role of demographic variables in accounting for variation in local public spending. He finds relatively weak evidence that households with similar demographic characteristics exhibit similar preferences, but one of the cases for which his evidence is strongest is the homogeneity of households with school-age children.

${ }^{7}$ The dependent variable is total government spending on K-12 education divided by the state population aged 5-17. Using population rather than enrollment as the divisor avoids the potential endogeneity problems associated with decisions to use private schools, but it also makes it difficult to interpret the dependent variable as a per-pupil-expenditure measure for public schools.
} 
line (POVERTY). Both the education spending variable and the federal aid variable reflect outlays by state as well as local governments. The ED variable is drawn from various issues of Government Finances, and federal aid to primary and secondary education is computed from information reported in the Tax Foundation's publication Facts and Figures on Government Finance.

Most of the independent variables have been found to be statistically significant explanators of state spending in previous empirical studies. Several variables deserve particular comment, however. The OWNERS variable proxies for the after-tax price of education spending, since the fraction of state residents who itemize income tax deductions and therefore can deduct state and local taxes from their federal income taxes is strongly affected by the percentage of homeowners. It may also capture differences in taste for educational spending between those who own homes and those who do not. The NONWHITE variable is interpreted by Cutler, Elmendorf, and Zeckhauser [1993] as testing whether racial mix affects support for public spending. It's interpretation is difficult, however, since it may also proxy for higher moments of the income distribution, such as the fraction of households with low income levels or the fraction living in large cities. To allow for these possibilities, some equations include the logarithm of the fraction of the state's population living below the poverty line (POVERTY) or in urban areas (URBAN). The URBAN variable has an independent rationale for inclusion: it may capture potential differences in the cost of delivering school services as a function of the spatial distribution of population, as well as potential taste differences for public spending between urban and rural residents. 
The estimation equation is:

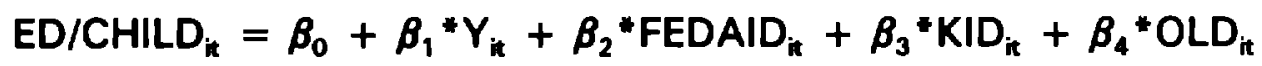

$$
\begin{aligned}
& +\beta_{5}{ }^{*} \text { OWNERS }_{\mathrm{in}}+\beta_{\mathrm{g}} \text { NONWHITE }_{\mathrm{it}}+\beta_{7} \text { URBAN }_{\mathrm{it}}+\beta_{\mathrm{g}} \text { "POVERTY }_{\mathrm{it}}+\epsilon_{\mathrm{in}} \text {. }
\end{aligned}
$$

All of the variables are measured in logarithms, so the estimated coefficients can be interpreted as "elasticities." There is relatively little year-to-year variation in most of the variables in this specification, so the data base includes observations on each state every ten years. Since the decennial U.S. Census of Population and Housing provides the necessary demographic information, it is natural to estimate the model using data on education spending from fiscal years 1961, 1971, 1981, and 1991. Nominal values from different years are deflated using the implicit price deflator for state and local government purchases, as reported in the 1996 Economic Report of the President. All of the analysis is limited to the forty-eight continental states, so there are a total of 192 state-year observations.

There are many state-specific factors that may affect per capita government spending in a state, such as a high average wage which raises the cost of hiring teachers. There are also time-specific factors, such as the rise of court- and legislature-imposed special education spending. To recognize the potential influence of such effects, the equations are estimated allowing for state and time fixed effects in the estimation, so that $\epsilon_{\mathrm{i}}=\delta_{\mathrm{i}}+r_{\mathrm{t}}+\lambda_{\mathrm{in}}$. In this case the coefficients of interest are identified from within-state (over time) variation in demographic structure that can not be explained by economy-wide shocks to demographics or spending levels.

Table 2 presents summary statistics on the panel data set. The first and 
second columns report means and standard deviations of variables in levels, even though logs are used in the estimation. The mean level of per-child spending in the sample is $\$ 3058$, with a coefficient of variation of slightly less than one third. Although summary statistics from single-year cross section data sets are not reported in Table 2, the coefficient of variation for per-child spending in each of the crosssection years is very similar to that in the panel. The key demographic variables also display substantial variation. The standard deviation of the share of the population aged 5-17 is .034 , and the analogous measure for the population share aged $65+$ is .022. The most youthful state has $29.6 \%$ of its population in the 5-17 age group, and its school age population share is twice as high the share in the oldest one. The population share aged $65+$ in different states ranges from $5.4 \%$ to $18.2 \%$.

The NONWHITE variable ranges from near zero to more than forty percent in the state-year sample. The average value of NONWHITE is .117 , but this masks a substantial trend over time. This fraction rises by more than four percentage points, on average, between 1960 and 1990 . The cross-sectional standard deviation of NONWHITE declines over the sample period. ${ }^{8}$

Rather than focusing on the NONWHITE coefficient as a test of ethnic group competition, the present analysis focuses on how differences in racial composition

\footnotetext{
${ }^{8}$ Nonwhites have historically been less likely than whites to vote, although racial differences in voter turnout have declined in recent years [see Filer, Kenny, and Morton, 1991]. Changes in nonwhite voter participation could lead to variation over time in the size and interpretation of the coefficient on this variable.
} 
between the elderly and the school-age population affect the level of school spending. ${ }^{9}$ The key explanatory variable is the fraction of non-whites in the school age (5-17) group, minus the fraction of non-whites in the elderly $(65+)$ population. The mean and standard deviation for this variable are shown in the last row of Table 2. On average, the nonwhite share of the school aged population is 6.5 percentage points higher than the nonwhite share of the $65+$ population. There is substantial range and variation in this aspect of demographic structure, with the maximum difference $23.2 \%$ (Florida) and the smallest $-0.6 \%$. West Virginia and Maine are the only continental states with a greater non-white share in the over-65 population than in the school-age population. The mean difference in the nonwhite population shares increased by nearly six percentage points between 1960 and 1990 .

There are substantial differences across states in the degree of ethnic and age heterogeneity. Florida exhibits the greatest disparity between the fraction of nonwhites in the 5-17 population and that in the $65+$ population; this is largely the result of immigration by elderly white households and younger Latino households. The other high-disparity states include a number of states in the industrial North, such as New York, New Jersey, and Illinois, as well as several states from the South, such as Mississippi and South Carolina.

${ }^{9}$ There is in principle no link between the NONWHITE variable and the differential racial composition of the two groups. One could envision a state with a large nonwhite population spread evenly across the age distribution, as well as one with a young nonwhite population and few elderly non whites. Thus NONWHITE could be the same in two cases, but the differential age composition variable would be very different. 
Given the difficulties of interpreting the various coefficients in the reduced form model described above, it is helpful to estimate a "control specification" that may provide evidence on spurious relationships. To this end, the ED/CHILD variable in equation (1) is replaced with NONED/POP, the level of per-capita spending on programs other than education. Estimating this equation can provide some insight on whether demographic and other variables are simply capturing differences across states in the taste for public spending, or whether they are capturing allocative effects with respect to education and other programs.

\section{Empirical Evidence on Demographic Variation and Education Spending}

This section presents the central empirical findings with respect to demographic variation and education spending. The first sub-section reports the basic results, while the second sub-section considers several models in which demographic structure is interacted with other variables that might alter its impact on spending levels.

\subsection{Results from Basic Specifications}

Table 3 presents the results of estimating regression models for school expenditures without the variable measuring the ethnic differences between the elderly and school-age population. The parallel equations in Table 5 include this variable in the specification. Tables 4 and 6 present similar regression models in 
which the dependent variable is per capita non-school direct spending. ${ }^{10}$ For completeness, the first column in each table shows the effect of ordinary least squares estimation without either state or time fixed effects. The equations in all subsequent columns include these effects.

The results in Table 3 suggest that the fraction of children and elderly in the population affect per-child spending on education. The share of elderly in the population is negatively related to this spending variable in the equations that include state and time fixed effects. These estimates suggest an elasticity of per-child spending with respect to the over-65 population share of approximately -.25 . The results are attenuated when the fraction of the population in urban areas is included in the specification; in this case the estimated coefficient is not statistically significant at conventional significance levels. The estimates in either the second or fourth column of Table 3 imply that a one standard deviation change in the share of elderly in the population, a shift from .108 to .130 , results in almost of five percent decline in per-pupil education spending. The results suggest that all else equal, jurisdictions with more elderly voters spend less on public schools. ${ }^{11}$

\footnotetext{
${ }^{10}$ The FEDAID variable in the control equations for non-education spending is the same variable, federal aid for K-12 education, as in the education equations. While this is not ideal from the standpoint of explaining cross-state variation in noneducation spending, it does provide a check for spurious results in the education equation.

"A key issue for future research is why they spend less. This may simply reflect a lack of support among elderly voters for public programs that do not benefit the elderly, or it may reflect a higher cost of raising funds in states with more elderly because of pre-existing demands that elderly populations place on public coffers.
} 


\section{7}

These results are strengthened by comparing them with the "control equation" findings in Table 4, where the estimates suggest that a larger elderly population in a state leads to higher spending on non-education programs. Thus it does not appear that the fraction of elderly individuals in the population is simply capturing a tendency for elderly voters to support lower levels of public spending in general.

The fraction of the population of school-age also has a strong effect on perchild spending. In the OLS equation in the first column, the estimated elasticity is .40, while after the equations include controls for state and time effects, the estimated elasticity rises to nearly -1.0 . These results, if interpreted literally, suggest that education spending per capita is independent of the share of school-aged children, suggesting that an increase in the population share in this age group leads to a proportionate reduction in per-child spending.

These striking results should be viewed with caution for several reasons. First, the "control equations" in Table 4 suggest that a higher population share of school age reduces non-school spending per capita, with an elasticity of approximately - .30 . The results in Table 3 suggest that per capita school spending is independent of the fraction of school-aged children in the population. This implies that an increase in the school-aged population reduces state and local government spending per capita, but raises the share of such spending that flows to education.

Second, the differences between the results of the OLS estimation (Table 3 column 1) and the fixed effects specification may indicate that economy-wide changes in the share of children in the population are associated with different types of 
spending response than idiosyncratic, state-specific demographic shocks. Conventional wisdom holds that rising K-12 enrollments were a key factor in the growth of state and local spending in the late 1950s and 1960s, and again in the 1990s. The specifications that allow for year effects remove such systematic changes in the size of the school-age population from the analysis. If the enrollment in a single state rises, competitive tax pressures and other factors may lead to smaller spending increases than when the school-aged population in the entire economy increases.

Finally, the results suggesting a strong negative effect of student cohort size on spending per pupil are consistent with a number of previous studies of spending on public schools. Case, Hines, and Rosen [1993] find significant negative effects of the school-aged proportion of the population on per-child school spending, even though several earlier studies, including Denzau [1975], Ladd [1975], and Megdal [1984], found small effects. Borge and Rattso [1995] find slow adjustment to demographic shocks in the composition of spending in Norway, along with a negative correlation between group size and per-person spending. Further analysis of the link between cohort size and per-pupil spending, perhaps using changes in enrollment that result from exogenous shocks such as changes in school district boundaries, seems warranted. ${ }^{12}$

\footnotetext{
${ }^{12}$ Equations not reported here also explored how other demographic variables, such as the number of children per household or the fraction of households with children, are related to the level of education spending. These variables did not have statistically significant effects on school spending per child after the current variables (school-age share and elderly share) were included in the regressions.
} 
A central issue in interpreting these results is whether they arise from differences in the "demand" for educational spending, mediated through the political process, or differences in the technology of supplying educational services to jurisdictions with different demographic characteristics. It seems reasonable to exclude the share of the local population over the age of 65 , and the ethnic composition of this group, from the education production function. This suggests that the demographic effects associated with these variables are likely to result from demand-side factors. Interpretation of the effect of fluctuations in the school-age population is more difficult, because economies of scale in education could make it possible to deliver the same education to a larger cohort with less than a proportionate expansion in educational spending. This is an issue that requires further exploration.

The estimated effects of the other independent variables in Tables 3 and 4 can be described briefly. The relationship between per capita income and per child school spending is weak but positive, and is highly affected by the inclusion of state and time fixed effects as well as the fraction of the state population living below the poverty line. Without POVERTY in the specification, the estimated income elasticity of school spending is approximately .50; without this variable, the income elasticity is on the order of .75 . Federal grants to the state have a statistically significant positive effect on the level of per-child school spending, although once again the coefficient is substantially reduced when state and time effects are included in the model.

States with a higher fraction of homeowners spend more on education, consistent with the view that homeowners face a lower marginal tax price of public 
spending. The OWNERS variable may also capture differences in the taste for public spending on education between homeowners and renters. The NONWHITE fraction of the population does not exhibit strong predictive power for the level of per-child spending. Including the URBAN variable has little effect on the coefficient of the share of the population of school age, but it does reduce the coefficient on the share of elderly individuals in the population. The URBAN variable has a significant effect on spending as well, with a one percent increase in the state population in urban areas reducing per-child spending by about 0.4 percent.

Table 5 presents results that are similar to those in Table 3, but each specification now includes the variable for racial heterogeneity between the 5-17 and $65+$ segments of the population. While the estimated coefficient on this variable is positive in the OLS estimates, the coefficient is negative (although not statistically significant at standard confidence levels) when the model includes state and time effects. Including this variable does not substantially affect the estimated coefficients for either the aged share or school-aged share of the population.

The estimates suggest that demographic heterogeneity can have a substantively important effect on education spending. The point estimates for this variable must be interpreted differently from those for other variables, because this variable is entered in levels rather than logarithms. The estimate in Table 5, column 2 suggests that a one percentage point increase in the share of nonwhites in the 0-17 population, holding the share of nonwhites in the $65+$ population constant, reduces the log of 
per-child school spending by -.006 , or approximately one half of one percent. ${ }^{13}$ These findings suggest that an increase in the fraction of a jurisdiction's population over the age of 65 tends to reduce per-child school spending, and that the effect is especially pronounced when the elderly residents are from a different ethnic group than the school-aged population. ${ }^{14}$

Table 6 presents results similar to those in Table 5, but with per capita nonschool spending as the dependent variable. The results for the racial heterogeneity variable are distinctly different from those in Table 5. The coefficient estimates are positive, and in all four specifications the null hypothesis of zero effect can be rejected. These results bolster the argument that demographic heterogeneity tends to reduce spending on education, particularly in relation to spending on other programs.

\subsection{Factors that Affect the Demography-Spending Link}

The results in the last subsection suggest that the elderly fraction in the population affects the level of per-child school spending, and that racial heterogeneity

\footnotetext{
${ }^{13}$ The demographic heterogeneity variable is included in levels, rather than logs, because it takes some negative values. The standard deviation of the percentage of whites in the over-65 (0-17) population is .084 (.116). Because these two percentages covary positively, however, the standard deviation of their difference is only .047.

${ }^{14}$ To explore the robustness of the findings on demographic heterogeneity, I separated this variable into two separate variables, (\% Nonwhite Age 5-17) and (\% Nonwhite Age $65+1$, and included both in the regression specification. The resulting estimates did not reject the null hypothesis that the coefficients on these two variables are of opposite signs but equal absolute value.
} 
across age groups can also have a negative effect on such spending. This subsection explores two aspects of this interaction: whether these effects are stronger in states with a high degree of population mobility, and whether these effects are attenuated by property tax circuit-breaker rules that limit property tax burdens, particularly for older residents.

To address the impact of population mobility, a variable from the decennial census indicating the fraction of the state population that resided in the state five years ago is added to the basic specification. This variable is also interacted with the logarithm of the elderly share of the population, and the difference in the racial mix between the $65+$ and school-age population. The resulting equation estimates are shown in the first two columns of Table 7. The estimates in the first column suggest that states with low population turnover (high values of Percent in State Five Years Agol spend more per child on public schools, although the estimated effects are not statistically significantly different from zero.

There is also evidence of an intriguing, but imprecise, interaction effect with the percent elderly in the population. In a state in which all of the residents had been there five years ago, the percent elderly variable would have essentially no effect on school spending. In a state with only half of the population resident for five or more years, the estimated elasticity of school spending with respect to the elderly share would be $-.50 .^{15}$ The interaction effects with respect to the racial heterogeneity

\footnotetext{
${ }^{15}$ The fraction of five year residents varies between .64 and .94 in the panel data sample, with a standard deviation of .059 and a mean of .86 .
} 
variable operate in the same direction, so the effect of this variable is reduced when the state's population consists of primarily long-term residents. However, the effects in this case are estimated with too little precision for further discussion.

The last two columns of Table 7 report estimates of equations that include an indicator variable for whether or not the state has a property tax circuit-breaker provision $^{10}$, and interactions of this variable with the demographic variables. The effects are similar to those for the long-term residence variable. States with property tax circuit breakers exhibit higher per-child school spending, and in such states, the effect of a rising share of elderly in the population is also reduced. The standard errors for both of the relevant coefficients are roughly as large as the estimated coefficients, however, so it is difficult to draw strong conclusions. When the circuitbreaker variable is interacted with the variable measuring racial heterogeneity, the heterogeneity coefficient itself falls to nearly zero, and the estimates suggest that states with circuit-breaker laws have larger negative effects of racial heterogeneity. Once again, however, the estimated effects are not significant at conventional levels of statistical significance.

The link between property tax circuit breakers and demographic tension is an issue that warrants further study. Better information on the nature of circuit-breakers, particularly on whether they apply only to elderly residents or to all residents, would result in more precise tests of how demographics interact with these institutions. In

\footnotetext{
${ }^{10}$ These variables are created by referring to various publications of the Advisory Council on Intergovernmental Relations.
} 
addition, the circuit breakers are examples of endogenous fiscal institutions, and further work could explicitly model this endogeneity and attempt to find valid instruments for studying the effect of circuit breakers on spending levels.

\section{Conclusions}

This paper presents empirical results suggesting that demographic structure affects the level and composition of public spending. The empirical analysis, which focuses on public spending for K-12 education, indicates that an increase in the fraction of elderly residents in a state is associated with a significant reduction in per child educational spending. This reduction is even larger when the elderly residents are predominantly from a different racial group than the school-age population. These results suggest that students who are part of larger school-age cohorts receive lower per-student spending than those in smaller cohorts. ${ }^{17}$

These findings, if they in fact reflect tensions between generations in the allocation of public funds, suggest that the changing demographic profile of the United States may lead to long-term reductions in the level of per-child school expenditure. Projections suggesting that the fraction of the population aged $65+$ will rise from $\mathbf{1 2 . 5}$ percent in 1990 to $\mathbf{1 8 . 7}$ percent in 2030 , would translate lusing the central estimates in the present study) into a ten percent reduction in per child spending. The

\footnotetext{
${ }^{17}$ Figlio (1997) relates the level of per pupil spending in the late 1980 s to changes in enrollment in the late 1970s, and finds evidence that rising enrollment is associated with lower spending levels. This raises issues about the long-term persistence of demographic effects and warrants further exploration.
} 
implications of such changes for income inequality and economic growth depend on controversial parameters linking school spending to school outcomes and wages, but the potential effects could be substantial.

These results raise, but do not resolve, questions about how fiscal institutions and the structure of the political process more generally may affect the degree of generational tension in allocating public spending. Mechanisms that move education finance closer to benefit taxation, such as property tax circuit-breakers, are one device that might be used to reduce generational conflict. Tying education spending to programs that benefit other community residents, for example building a school that is used as an elder center for part of the week, is another option. The prospective decline in the share of the population with children in public school systems may dictate greater attention to these mechanisms.

The results presented in this paper raise a number of broader issues for evaluating how demographic change is likely to affect the structure of government programs. First, the mechanism through which demographic structure affects the composition of government spending requires further analysis. If a particular demographic group such as the elderly place substantial demands on the public sector, and this raises non-education government spending, then the shadow cost of funds for education will rise, and this spending program is likely to contract. Second, it is possible that elderly voters do not assign high priority to spending for education. In this case, jurisdictions where elderly voters are more important will spend less on education as a result of the different tastes of their voting population. Further work 


\section{6}

is needed to disentangle these alternative explanations of the empirical findings. Finally, the results suggest the potential importance of normative questions concerning community composition. Benabou [1995] and Schwab and Oates [1991], among others, have analyzed the problem of optimal community structure, with particular attention to the optimal degree of heterogeneity in community composition; the present findings suggest the potential relevance of these studies in considering the age composition of communities.

James M. Poterba, Mitsui Professor of Economics, Massachusetts Institute of Technology. 


\section{REFERENCES}

Benabou, Roland (1995), "The Workings of a City," mimeo, New York University.

Bergstrom, Theodore C., and Richard Goodman (1973), Private Demands for Public Goods," American Economic Review 63, pp. 280-296.

Borcherding, Thomas E. and Robert T. Deacon (1972), "The Demand for the Services of Non-Federal Governments," American Economic Review 62, pp. 891-901. Borge, Lars-Erik and Jorn Rattso (1995), "Demographic Shift, Relative Costs, and the Allocation of Local Public Consumption in Norway," Regional Science and Urban Economics 25, pp. 705-726.

Button, James W. (1992), "A Sign of Generational Conflict: The Impact of Florida's Aging Voters on Local School and Tax Referenda," Social Science Quarterly 73, pp. 786-797.

Case, Anne C., James R. Hines, and Harvey S. Rosen (1993), "Budget Spillovers and Fiscal Policy Interdependence: Evidence From the States," Journal of Public Economics 52, pp. 285-308.

Chomitz, Kenneth M. (1985), "Demographic Influences on Local Public Education Expenditure: A Review of Econometric Evidence," paper presented to National Academy of Sciences Workshop on Demographic Change and the Well Being of Children.

Cutler, David M., Douglas W. Elmendorf, and Richard J. Zeckhauser (1993), "Demographic Characteristics and the Public Bundle," Public Finance/Finances Publiques 48, pp. 178-198.

Denzau, Arthur T. (1975), "An Empirical Survey of Studies on Public School 
Spending," National Tax Journal XXVIII, pp. 241-249.

Downes, Thomas A. (1996), "An Examination of the Structure of Governance in California School Districts Before and After Proposition 13," Public Choice 86, pp. 297-307.

Figlio, David (1997), "Did the Tax Revolt Reduce School Performance?," Journal of Public Economics (forthcoming).

Filer, John E., Lawrence W. Kenny, and Rebecca B. Morton (1991), "Voting Laws, Educational Policies, and Minority Turnout," Journal of Law and Economics 34, pp. 371-393.

Gross, John (1995), "Heterogeneity of Preferences for Local Public Goods: The Case of Private Expenditure on Public Education," Journal of Public Economics 57, pp. 103-128.

Inman, Robert P. (1978), "Testing Political Economy's 'As If' Proposition: Is the Median Income Voter Really Decisive?," Public Choice 33, pp.45-65.

Inman, Robert P. (1987), "Markets, Governments, and the New Political Economy," in A. Auerbach and M. Feldstein (eds.), Handbook of Public Economics: Volume 2 (Amsterdam: North Holland).

Ladd, Helen F. (1975), "Local Educational Expenditures, Fiscal Capacity, and the Composition of the Property Tax Base," National Tax Journal XXVIII, pp. 145158.

Lindert, Peter H. (1996), "What Limits Social Spending?," Explorations in Economic History 33, pp. 1-34. 
Logan, John R. and Glenna Spitze (1995), "Self Interest and Altruism in Intergenerational Relations," Demography 32, pp. 353-364.

Lott, John R., Jr. (1987), "Why Is Education Publicly Provided? A Critical Survey," Cato Journal 7, pp. 475-501.

Megdal, Sharon B. (1984), "A Model of Local Demand for Education," Journal of Urban Economics 16, pp. 13-30.

O'Higgins, Michael (1988), "The Allocation of Public Resources to Children and the Elderly in OECD countries," in John L. Palmer, Timothy Smeeding, and Barbara Boyle Torrey (eds.), The Vulnerable (Washington: The Urban Institute Press). Organization for Economic Cooperation and Development (1988a), Ageing Populations: The Social Policy Implications (Paris: OECD).

Organization for Economic Cooperation and Development (1988b), Reforming Public Pensions (Paris: OECD).

Peltzman, Sam (1993), "The Political Economy of the Decline of American Public Education," Journal of Law and Economics 36, pp. 331-370.

Poterba, James M. (1995a), "Government Intervention in Markets for Education and Health: Why and How," in V. Fuchs (ed.), Individual and Social Responsibility (Chicago: University of Chicago Press).

Poterba, James M. (1995b), "Capital Budgets, Borrowing Rules, and State Capital Spending," Journal of Public Economics 56, pp. 165-188.

Preston, Samuel (1984), "Children and the Elderly in the United States," Demography 21, pp. 435-457. 
Richman, Harold A. and Matthew W. Stagner (1986), "Children: Treasured Resource or Forgotten Minority?," in Alan Pifer and Lydia Bronte (eds.), Our Aging Society: Paradox and Promise (New York: W.W. Norton).

Rubinfeld, Daniel L. (1977), "Voting in a Local School Election: A Micro Analysis," Review of Economics and Statistics 59, pp. 30-42.

Rubinfeld, Daniel L. and Perry Shapiro (1989), "Micro-estimation of the Demand for Schooling: Evidence from Michigan and Massachusetts, " Regional Science and Urban Economics 19, pp. 381-398.

Schwab, Robert M. and Wallace E. Oates (1991), "Community Composition and the Provision of Local Public Goods: A Normative Analysis," Journal of Public Economics 44, 217-238.

Smeeding, Timothy, Barbara Boyle Torrey, and Martin Rein (1988), "Patterns of Income and Poverty: The Economic Status of Children and the Elderly in Eight Countries," in John L. Palmer, Timothy Smeeding, and Barbara Boyle Torrey (eds.), The Vulnerable (Washington: The Urban Institute Press).

Weingast, Barry R., Kenneth Shepsle, and C. Johnsen (1981), "The Political Economy of Benefits and Costs: A Neoclassical Approach to Distributive Politics, " Journal of Political Economy 89, pp. 642-664. 
Table 1: Relative Per-Capita Social Spending By Age Group, 1980

\begin{tabular}{llcc} 
& $\begin{array}{c}\text { Relative Spending } \\
\text { Ages 15-64 }\end{array}$ & $\begin{array}{c}\text { (Age } 14=100 \text { ) } \\
\text { Ages 65 }+\end{array}$ & $\begin{array}{c}\text { Population Share } \\
\text { Aged 65 + }\end{array}$ \\
\hline Canada & 72 & 265 & $9.5 \%$ \\
France & 51 & 263 & 14.0 \\
Germany & 60 & 316 & 15.5 \\
Italy & 110 & 380 & 13.5 \\
Japan & 44 & 235 & 9.1 \\
Sweden & 43 & 234 & 16.3 \\
United Kingdom & 54 & 213 & 14.9 \\
United States & 67 & 381 & 11.3 \\
\hdashline
\end{tabular}

Source: Columns one and two are drawn from OECD [1988a], Table 18. Column three is from [1988b], Table 3.1. 
Table 2: Summary Statistics, 1961 - 1991 Panel Data Set

\begin{tabular}{|c|c|c|c|}
\hline Variable & Mean & $\begin{array}{l}\text { Standard } \\
\text { Deviation }\end{array}$ & $\begin{array}{r}\text { Maximum/ } \\
\text { Minimum }\end{array}$ \\
\hline $\begin{array}{l}\text { Per Child } \\
\text { School Spending }\end{array}$ & 3058 & 1164 & $\begin{array}{r}6884 I \\
1101\end{array}$ \\
\hline $\begin{array}{l}\text { Per Capita Non- } \\
\text { Education Spending }\end{array}$ & 1891 & 563 & $\begin{array}{r}4112 / \\
834\end{array}$ \\
\hline $\begin{array}{l}\text { Real Per Capita } \\
\text { Income }\end{array}$ & 14958 & 3537 & $\begin{array}{r}26810 / \\
6595\end{array}$ \\
\hline $\begin{array}{l}\text { Real Federal Aid } \\
\text { Per Capita }\end{array}$ & 224 & 119 & $\begin{array}{r}612 / \\
15\end{array}$ \\
\hline $\begin{array}{l}\text { Population Share } \\
\text { Aged 5-17 }\end{array}$ & 0.226 & 0.034 & $\begin{array}{r}.296 / \\
.157\end{array}$ \\
\hline $\begin{array}{l}\text { Population Share } \\
\text { Aged } 65+\end{array}$ & 0.108 & 0.022 & $\begin{array}{r}0.1821 \\
0.054\end{array}$ \\
\hline $\begin{array}{l}\text { Percent of Population } \\
\text { Below Poverty Line }\end{array}$ & 0.162 & 0.083 & $\begin{array}{r}0.545 / \\
0.064\end{array}$ \\
\hline $\begin{array}{l}\text { Percent of Population } \\
\text { Owning Homes }\end{array}$ & 0.669 & 0.056 & $\begin{array}{r}0.791 / \\
0.448\end{array}$ \\
\hline $\begin{array}{l}\text { Percent of Population } \\
\text { Nonwhite }\end{array}$ & 0.117 & 0.094 & $\begin{array}{r}0.422 / \\
0.002\end{array}$ \\
\hline $\begin{array}{l}\text { Percent of Population } \\
\text { in Urban Area }\end{array}$ & 0.655 & 0.146 & $\begin{array}{r}0.926 / \\
0.322\end{array}$ \\
\hline $\begin{array}{l}\text { Nonwhite Population } \\
\text { Share Aged 5-17 - } \\
\text { Nonwhite Population } \\
\text { Share Aged } 65+\end{array}$ & 0.065 & 0.048 & $\begin{array}{r}0.232 / \\
-0.006\end{array}$ \\
\hline
\end{tabular}


Table 3: Determinants of Per Child School Spending: Age-Related Demographics

\begin{tabular}{|c|c|c|c|c|}
\hline \multirow{2}{*}{$\begin{array}{l}\text { Variable } \\
\text { Constant }\end{array}$} & \multirow{2}{*}{$\begin{array}{l}\text { OLS } \\
3.082 \\
(0.604)\end{array}$} & \multicolumn{3}{|c|}{ With State and Time Fixed Effects } \\
\hline & & $\begin{array}{c}1.366 \\
(0.995)\end{array}$ & $\begin{array}{c}1.719 \\
(0.979)\end{array}$ & $\begin{array}{c}2.062 \\
(1.157)\end{array}$ \\
\hline $\begin{array}{l}\text { Real Per Capita } \\
\text { Income }\end{array}$ & $\begin{array}{c}1.067 \\
(0.068)\end{array}$ & $\begin{array}{c}0.672 \\
(0.148)\end{array}$ & $\begin{array}{c}0.776 \\
(0.149)\end{array}$ & $\begin{array}{c}0.528 \\
(0.192)\end{array}$ \\
\hline $\begin{array}{l}\text { Real Federal Aid } \\
\text { Per Capita }\end{array}$ & $\begin{array}{l}0.138 \\
(0.018)\end{array}$ & $\begin{array}{c}0.034 \\
(0.022)\end{array}$ & $\begin{array}{c}0.024 \\
(0.023)\end{array}$ & $\begin{array}{c}0.037 \\
(0.023)\end{array}$ \\
\hline $\begin{array}{l}\text { Population Share } \\
\text { Aged 5-17 }\end{array}$ & $\begin{array}{l}-0.404 \\
(0.132)\end{array}$ & $\begin{array}{l}-0.998 \\
(0.212)\end{array}$ & $\begin{array}{l}-0.940 \\
(0.208)\end{array}$ & $\begin{array}{l}-0.986 \\
(0.212)\end{array}$ \\
\hline $\begin{array}{l}\text { Population Share } \\
\text { Aged } 65+\end{array}$ & $\begin{array}{c}0.029 \\
(0.068)\end{array}$ & $\begin{array}{l}-0.276 \\
(0.121)\end{array}$ & $\begin{array}{l}-0.155 \\
(0.125)\end{array}$ & $\begin{array}{l}-0.264 \\
(0.121)\end{array}$ \\
\hline $\begin{array}{l}\text { Percent of Population } \\
\text { Owning Homes }\end{array}$ & $\begin{array}{c}0.163 \\
(0.130)\end{array}$ & $\begin{array}{c}0.645 \\
(0.240)\end{array}$ & $\begin{array}{c}0.535 \\
(0.237)\end{array}$ & $\begin{array}{c}0.646 \\
(0.240)\end{array}$ \\
\hline $\begin{array}{l}\text { Percent of Population } \\
\text { Nonwhite }\end{array}$ & $\begin{array}{l}-0.027 \\
(0.012)\end{array}$ & $\begin{array}{c}0.023 \\
(0.037)\end{array}$ & $\begin{array}{c}0.013 \\
(0.036)\end{array}$ & $\begin{array}{c}0.033 \\
(0.038)\end{array}$ \\
\hline $\begin{array}{l}\text { Percent of Population } \\
\text { in Urban Areas }\end{array}$ & & & $\begin{array}{l}-0.434 \\
(0.153)\end{array}$ & \\
\hline $\begin{array}{l}\text { Percent of Population } \\
\text { Below Poverty Line }\end{array}$ & & & & $\begin{array}{l}-0.094 \\
(0.080)\end{array}$ \\
\hline Adjusted $\mathbf{R}^{2}$ & 0.885 & 0.954 & 0.956 & 0.954 \\
\hline
\end{tabular}

Notes: Standard errors are shown in parentheses. Monetary values are reported in 1992 dollars. All variables are in logarithms. The sample consists of the 48 continental United States for the years 1961, 1971, 1981, and 1991. 
Table 4: Determinants of Per Capita Non-School Direct Spending

\begin{tabular}{|c|c|c|c|c|}
\hline \multirow{2}{*}{$\begin{array}{l}\text { Variable } \\
\text { Constant }\end{array}$} & \multirow{2}{*}{$\begin{array}{c}\text { OLS } \\
6.388 \\
(0.703)\end{array}$} & \multicolumn{3}{|c|}{ With State and Time Fixed Effects } \\
\hline & & $\begin{array}{c}4.448 \\
(0.976)\end{array}$ & $\begin{array}{c}4.477 \\
(0.988)\end{array}$ & $\begin{array}{r}5.270 \\
(1.132)\end{array}$ \\
\hline $\begin{array}{l}\text { Real Per Capita } \\
\text { Income }\end{array}$ & $\begin{array}{c}0.614 \\
(0.079)\end{array}$ & $\begin{array}{c}0.328 \\
(0.138)\end{array}$ & $\begin{array}{c}0.336 \\
(0.150)\end{array}$ & $\begin{array}{r}0.157 \\
(0.188)\end{array}$ \\
\hline $\begin{array}{l}\text { Real Federal Aid } \\
\text { Per Capita }\end{array}$ & $\begin{array}{c}0.134 \\
(0.021)\end{array}$ & $\begin{array}{c}0.014 \\
(0.022)\end{array}$ & $\begin{array}{c}0.013 \\
(0.023)\end{array}$ & $\begin{array}{r}0.017 \\
(0.022)\end{array}$ \\
\hline $\begin{array}{l}\text { Population Share } \\
\text { Aged 5-17 }\end{array}$ & $\begin{array}{l}-0.466 \\
(0.154)\end{array}$ & $\begin{array}{l}-0.286 \\
10.2081\end{array}$ & $\begin{array}{l}-0.282 \\
(0.210)\end{array}$ & $\begin{array}{l}-0.272 \\
(0.208)\end{array}$ \\
\hline $\begin{array}{l}\text { Population Share } \\
\text { Aged } 65+\end{array}$ & $\begin{array}{l}-0.013 \\
10.079)\end{array}$ & $\begin{array}{c}0.218 \\
(0.118)\end{array}$ & $\begin{array}{c}0.228 \\
(0.126)\end{array}$ & $\begin{array}{r}0.232 \\
(0.118)\end{array}$ \\
\hline $\begin{array}{l}\text { Percent of Population } \\
\text { Owning Homes }\end{array}$ & $\begin{array}{l}-0.508 \\
(0.151)\end{array}$ & $\begin{array}{c}0.617 \\
|0.236|\end{array}$ & $\begin{array}{c}0.608 \\
(0.240)\end{array}$ & $\begin{array}{r}0.618 \\
(0.235)\end{array}$ \\
\hline $\begin{array}{l}\text { Percent of Population } \\
\text { Nonwhite }\end{array}$ & $\begin{array}{l}-0.069 \\
(0.013)\end{array}$ & $\begin{array}{c}0.023 \\
(0.036)\end{array}$ & $\begin{array}{c}0.023 \\
(0.036)\end{array}$ & $\begin{array}{r}0.035 \\
10.037\end{array}$ \\
\hline $\begin{array}{l}\text { Percent of Population } \\
\text { in Urban Areas }\end{array}$ & & & $\begin{array}{l}-0.035 \\
(0.155)\end{array}$ & \\
\hline $\begin{array}{l}\text { Percent of Population } \\
\text { Below Poverty Line }\end{array}$ & & & & $\begin{array}{l}-0.111 \\
(0.078)\end{array}$ \\
\hline Adjusted $\mathbf{R}^{2}$ & 0.730 & 0.923 & 0.922 & 0.923 \\
\hline
\end{tabular}

Notes: Standard errors are shown in parentheses. Monetary values are reported in 1992 dollars. All variables are in logarithms. The sample consists of the 48 continental United States for the years 1961, 1971, 1981, and 1991. 
Table 5: Determinants of Per Child School Spending: Age Distribution and Ethnic Composition Effects

\begin{tabular}{|c|c|c|c|c|}
\hline \multirow{2}{*}{$\begin{array}{l}\text { Variable } \\
\text { Constant }\end{array}$} & \multirow{2}{*}{$\begin{array}{c}\text { OLS } \\
4.293 \\
(0.628)\end{array}$} & \multicolumn{3}{|c|}{ With State and Time Fixed Effects } \\
\hline & & $\begin{array}{c}1.522 \\
(0.995)\end{array}$ & $\begin{array}{c}1.827 \\
(0.980)\end{array}$ & $\begin{array}{r}2.070 \\
(1.153)\end{array}$ \\
\hline $\begin{array}{l}\text { Real Per Capita } \\
\text { Income }\end{array}$ & $\begin{array}{c}0.973 \\
(0.065)\end{array}$ & $\begin{array}{c}0.639 \\
(0.149)\end{array}$ & $\begin{array}{c}0.744 \\
(0.150)\end{array}$ & $\begin{array}{r}0.525 \\
(0.191)\end{array}$ \\
\hline $\begin{array}{l}\text { Real Federal Aid } \\
\text { Per Capita }\end{array}$ & $\begin{array}{c}0.073 \\
(0.020)\end{array}$ & $\begin{array}{c}0.032 \\
(0.023)\end{array}$ & $\begin{array}{c}0.023 \\
(0.022)\end{array}$ & $\begin{array}{r}0.034 \\
(0.023)\end{array}$ \\
\hline $\begin{array}{l}\text { Population Share } \\
\text { Aged 5-17 }\end{array}$ & $\begin{array}{l}-0.062 \\
(0.128)\end{array}$ & $\begin{array}{l}-1.025 \\
(0.212)\end{array}$ & $\begin{array}{l}-0.965 \\
(0.208)\end{array}$ & $\begin{array}{l}-1.013 \\
(0.212)\end{array}$ \\
\hline $\begin{array}{l}\text { Population Share } \\
\text { Aged } 65+\end{array}$ & $\begin{array}{l}-0.037 \\
(0.064)\end{array}$ & $\begin{array}{l}-0.244 \\
(0.122)\end{array}$ & $\begin{array}{l}-0.136 \\
(0.126)\end{array}$ & $\begin{array}{l}-0.238 \\
(0.122)\end{array}$ \\
\hline $\begin{array}{l}\text { Percent of Population } \\
\text { Owning Homes }\end{array}$ & $\begin{array}{c}0.121 \\
(0.121)\end{array}$ & $\begin{array}{c}0.654 \\
(0.239)\end{array}$ & $\begin{array}{c}0.548 \\
(0.237)\end{array}$ & $\begin{array}{r}0.654 \\
(0.239)\end{array}$ \\
\hline $\begin{array}{l}\text { Percent of Population } \\
\text { Nonwhite }\end{array}$ & $\begin{array}{l}-0.048 \\
(0.015)\end{array}$ & $\begin{array}{c}0.037 \\
(0.037)\end{array}$ & $\begin{array}{c}0.024 \\
(0.037)\end{array}$ & $\begin{array}{r}0.043 \\
(0.038)\end{array}$ \\
\hline $\begin{array}{l}\text { Percent of Population } \\
\text { in Urban Areas }\end{array}$ & & & $\begin{array}{l}-0.411 \\
(0.154)\end{array}$ & \\
\hline $\begin{array}{l}\text { Percent of Population } \\
\text { Below Poverty Line }\end{array}$ & & & & $\begin{array}{l}-0.076 \\
(0.081)\end{array}$ \\
\hline $\begin{array}{l}\text { Nonwhite Percent of } \\
\text { Age 5-17 Population } \\
\text { - Nonwhite Percent } \\
\text { of } 65+\text { Population }\end{array}$ & $\begin{array}{c}0.770 \\
(0.342)\end{array}$ & $\begin{array}{l}-0.621 \\
(0.394)\end{array}$ & $\begin{array}{l}-0.502 \\
(0.388)\end{array}$ & $\begin{array}{l}-0.561 \\
(0.400)\end{array}$ \\
\hline Adjusted $\mathbf{R}^{2}$ & 0.908 & 0.954 & 0.956 & 0.954 \\
\hline
\end{tabular}

Notes: Standard errors are shown in parentheses. Monetary values are reported in 1992 dollars. All variables are in logarithms except for the difference between the nonwhite shares of the population aged 5-17 and 65+. The sample consists of the 48 continental United States for the years 1961, 1971, 1981, and 1991. 
Table 6: Determinants of Per Capita Non-Education Direct Spending Age Distribution and Ethnic Composition Effects

\begin{tabular}{|c|c|c|c|c|}
\hline \multirow{2}{*}{$\begin{array}{l}\text { Variable } \\
\text { Constant }\end{array}$} & \multirow{2}{*}{$\begin{array}{c}\text { OLS } \\
7.713 \\
(0.736)\end{array}$} & \multicolumn{3}{|c|}{ With State and Time Fixed Effects } \\
\hline & & $\begin{array}{c}4.251 \\
(0.970)\end{array}$ & $\begin{array}{c}4.304 \\
(0.979)\end{array}$ & $\begin{array}{c}5.256 \\
(1.114)\end{array}$ \\
\hline $\begin{array}{l}\text { Real Per Capita } \\
\text { Income }\end{array}$ & $\begin{array}{l}0.475 \\
(0.073)\end{array}$ & $\begin{array}{c}0.369 \\
(0.144)\end{array}$ & $\begin{array}{c}0.388 \\
(0.130)\end{array}$ & $\begin{array}{c}0.161 \\
(0.184)\end{array}$ \\
\hline $\begin{array}{l}\text { Real Federal Aid } \\
\text { Per Capita }\end{array}$ & $\begin{array}{c}0.060 \\
(0.023)\end{array}$ & $\begin{array}{c}0.017 \\
(0.022)\end{array}$ & $\begin{array}{c}0.016 \\
(0.022\rangle\end{array}$ & $\begin{array}{c}0.021 \\
(0.022)\end{array}$ \\
\hline $\begin{array}{l}\text { Population Share } \\
\text { Aged 5-17 }\end{array}$ & $\begin{array}{l}-0.072 \\
(0.150)\end{array}$ & $\begin{array}{l}-0.252 \\
(0.206)\end{array}$ & $\begin{array}{l}-0.242 \\
(0.208 \mid\end{array}$ & $\begin{array}{l}-0.229 \\
(0.205)\end{array}$ \\
\hline $\begin{array}{l}\text { Population Share } \\
\text { Aged } 65+\end{array}$ & $\begin{array}{l}-0.126 \\
(0.075)\end{array}$ & $\begin{array}{c}0.179 \\
(0.119)\end{array}$ & $\begin{array}{c}0.197 \\
(0.126)\end{array}$ & $\begin{array}{r}0.190 \\
(0.118)\end{array}$ \\
\hline $\begin{array}{l}\text { Percent of Population } \\
\text { Owning Homes }\end{array}$ & $\begin{array}{l}-0.545 \\
(0.141)\end{array}$ & $\begin{array}{c}0.605 \\
(0.233)\end{array}$ & $\begin{array}{c}0.587 \\
(0.237)\end{array}$ & $\begin{array}{c}0.606 \\
(0.231)\end{array}$ \\
\hline $\begin{array}{l}\text { Percent of Population } \\
\text { Nonwhite }\end{array}$ & $\begin{array}{l}-0.111 \\
(0.017)\end{array}$ & $\begin{array}{c}0.007 \\
(0.036)\end{array}$ & $\begin{array}{c}0.005 \\
(0.037)\end{array}$ & $\begin{array}{c}0.019 \\
(0.036)\end{array}$ \\
\hline $\begin{array}{l}\text { Percent of Population } \\
\text { in Urban Areas }\end{array}$ & & & $\begin{array}{l}-0.071 \\
(0.154)\end{array}$ & \\
\hline $\begin{array}{l}\text { Percent of Population } \\
\text { Below Poverty Line }\end{array}$ & & & & $\begin{array}{l}-0.140 \\
(0.078)\end{array}$ \\
\hline $\begin{array}{l}\text { Nonwhite Percent of } \\
\text { Age 5-17 Population } \\
\text { - Nonwhite Percent } \\
\text { of } 65+\text { Population }\end{array}$ & $\begin{array}{c}1.258 \\
(0.400)\end{array}$ & $\begin{array}{c}0.785 \\
(0.384)\end{array}$ & $\begin{array}{c}0.806 \\
(0.388)\end{array}$ & $\begin{array}{c}0.895 \\
(0.386)\end{array}$ \\
\hline Adjusted $\mathbf{R}^{2}$ & 0.781 & 0.924 & 0.924 & 0.926 \\
\hline
\end{tabular}

Notes: Standard errors are shown in parentheses. Monetary values are reported in 1992 dollars. All variables are in logarithms except for the difference between the nonwhite shares of the population aged 5-17 and $65+$. The sample consists of the 48 continental United States for the years 1961, 1971, 1981, and 1991. 
Table 7: Per Child Education Spending: Migration \& Property Tax Circuit-Breaker Effects

\begin{tabular}{|c|c|c|c|c|}
\hline Constent & $\begin{array}{c}0.313 \\
(1.671)\end{array}$ & $\begin{array}{c}0.840 \\
(2.052)\end{array}$ & $\begin{array}{c}1.464 \\
(1.010)\end{array}$ & $\begin{array}{r}1.645 \\
(1.007)\end{array}$ \\
\hline $\begin{array}{l}\text { Real Per Capita } \\
\text { Income }\end{array}$ & $\begin{array}{c}0.644 \\
(0.153)\end{array}$ & $\begin{array}{c}0.626 \\
(0.154)\end{array}$ & $\begin{array}{c}0.656 \\
(0.150)\end{array}$ & $\begin{array}{c}0.611 \\
(0.150)\end{array}$ \\
\hline $\begin{array}{l}\text { Real Foderal Aid } \\
\text { Per Capita }\end{array}$ & $\begin{array}{c}0.017 \\
(0.025)\end{array}$ & $\begin{array}{c}0.014 \\
(0.027)\end{array}$ & $\begin{array}{c}0.025 \\
(0.024)\end{array}$ & $\begin{array}{l}0.017 \\
(0.024)\end{array}$ \\
\hline $\begin{array}{l}\text { Population Share } \\
\text { Aged 5-17 }\end{array}$ & $\begin{array}{l}-1.005 \\
(0.223)\end{array}$ & $\begin{array}{l}-1.051 \\
(0.226)\end{array}$ & $\begin{array}{l}-1.013 \\
(0.213)\end{array}$ & $\begin{array}{l}-1.058 \\
(0.211)\end{array}$ \\
\hline $\begin{array}{l}\text { Population Share } \\
\text { Aged } 65+\end{array}$ & $\begin{array}{l}-1.017 \\
|0.560|\end{array}$ & $\begin{array}{l}-0.779 \\
(0.680)\end{array}$ & $\begin{array}{l}-0.289 \\
(0.121)\end{array}$ & $\begin{array}{l}-0.227 \\
(0.123)\end{array}$ \\
\hline $\begin{array}{l}\text { Percent of Population } \\
\text { Owning Homes }\end{array}$ & $\begin{array}{c}0.587 \\
(0.242)\end{array}$ & $\begin{array}{c}0.606 \\
(0.243)\end{array}$ & $\begin{array}{c}0.636 \\
(0.241)\end{array}$ & $\begin{array}{c}0.668 \\
(0.239)\end{array}$ \\
\hline $\begin{array}{l}\text { Percent of Population } \\
\text { Nonwhite }\end{array}$ & $\begin{array}{c}0.047 \\
(0.040)\end{array}$ & $\begin{array}{c}0.058 \\
(0.041)\end{array}$ & $\begin{array}{c}0.027 \\
(0.037)\end{array}$ & $\begin{array}{c}0.045 \\
(0.037)\end{array}$ \\
\hline $\begin{array}{l}\text { Percent of Population in } \\
\text { Same State } 5 \text { Years Ago }\end{array}$ & $\begin{array}{c}2.172 \\
(1.747)\end{array}$ & $\begin{array}{l}1.545 \\
(2.158)\end{array}$ & & \\
\hline $\begin{array}{l}\text { (Seme State } 5 \text { Years Ago)* } \\
\text { Share Aged } 65+\end{array}$ & $\begin{array}{l}1.028 \\
(0.709)\end{array}$ & $\begin{array}{c}0.757 \\
(0.824)\end{array}$ & & \\
\hline $\begin{array}{l}\text { Indicator for Property } \\
\text { Tax Circuit Breaker }\end{array}$ & & & $\begin{array}{c}0.208 \\
(0.201)\end{array}$ & $\begin{array}{c}0.288 \\
(0.217)\end{array}$ \\
\hline $\begin{array}{l}\text { (Circuit Breaker)* } \\
\text { Share Aged } 65 \text { + }\end{array}$ & & & $\begin{array}{c}0.106 \\
(0.093)\end{array}$ & $\begin{array}{r}0.124 \\
(0.096)\end{array}$ \\
\hline $\begin{array}{l}\text { NW \% Population 5-17 } \\
- \text { NW \% Population } 65+\end{array}$ & & $\begin{array}{l}-2.360 \\
(4.412)\end{array}$ & & $\begin{array}{l}0.007 \\
10.542)\end{array}$ \\
\hline $\begin{array}{l}\text { (Same State } 5 \text { Yoars Ago) * } \\
\text { (NW \% 5-17-NW } \% 65 \text { +) }\end{array}$ & & $\begin{array}{l}2.067 \\
14.971)\end{array}$ & & \\
\hline $\begin{array}{l}\text { (Circuit Breaker)* } \\
\text { (NW \% 5-17-NW \% } 65+\text { ) }\end{array}$ & & & & $\begin{array}{l}-0.677 \\
10.4041\end{array}$ \\
\hline Adjusted $\mathbf{R}^{2}$ & 0.954 & 0.954 & 0.954 & 0.955 \\
\hline
\end{tabular}

Notes: Standard errors are shown in parentheses. Monetary values are reported in 1992 dollars. All equations include state and time fixed offects. All variables are in logarithms except for the difference between the nonwhite shares of the population aged 5-17 and 65 . The sample consists of the 48 continental United States for the years 1961, 1971, 1981, and 1991. 